\title{
BIOREMEDIATION OF FISH WASTEWATER USING A MODIFIED AERATED BEADS BIOLOGICAL FILTER
}

\author{
K. M. Abdelbary ${ }^{1}$
}

\section{ABSTRACT}

Bioremediation is a treatment that uses naturally occurring organisms (plants and animals) as agents of degrading pollutants to break down hazardous substances into less toxic or non-toxic substances. research work aim is to get treated water suitable for other purposes such as refarming out again and used to irrigate farms, especially vegetables and used in the cultivation of surfaces so that it works to reduce the burden on the Nile waters and contribute to the bridging part of the gap water poverty in Egypt. Experimental work was conducted in high pressure resistance glass aquarium supplied with two filter types; filter (A) spongy filter element, and aerated plastic granules (beads), filter (C), Crystal. Chemical analysis of initial water samples shows that EC of 1.23 mmohs/cm, pH of 7.4, ammonia concentration increased gradually from 5.59 to $183.75 \mathrm{mg} / \mathrm{L}$ after 11 days then decreased to $2.63 \mathrm{mg} / \mathrm{L}$ due biofiltration achievement and still remaining at a level under $25 \mathrm{mg} / \mathrm{L}$ till experiment end. Also, ammonia concentrations decreased to $2.63 \mathrm{mg} / \mathrm{L}$ for filter $(A)$ and to 1.31 for filter $(C)$ that was due to reverse cleaning of biofilter media to control a biomass clogging. Blank water nitrate concentration increased gradually from 0.00 to $26.69 \mathrm{mg} / \mathrm{L}$ after 14 days then decreased to 1.75 , then increased gradually again to a level of 45.5 mg/L after 27 days, due to loading increasing which led to increase competition for space and oxygen and affect biofilter capacity to complete nitrification process. Nitrate concentration of filter $(A)$ and $(C)$ increased progressively from 0.88 to $21.88 \mathrm{mg} / \mathrm{L}$ for filter $(A)$ and from 0.44 to 43.75 $\mathrm{mg} / \mathrm{L}$ for filter $(C)$ respectively, after 11 days from experiment beginning, acclimation periods for microbial population. Ammonia removal efficiencies ranged from 4.02 to $63.99 \%$ for filter $(A)$ and from 11.9 to $78.24 \%$ for filter $(C)$, ammonia elimination capacities were fluctuated between 2.28 and $67.98 \mathrm{~g} / \mathrm{L}$. h for filter $(A)$ and between 6.84 and 113.32 $\mathrm{g} / \mathrm{L}$. $h$ for filter $(C)$ respectively.

\footnotetext{
${ }^{1}$ Assist. Prof., Agric. Eng. Dept., Fac. of Agric., Cairo Univ., Giza, Egypt.
} 
Filter (C), a modified aerated beads biological filter, shows superiority in nitrate concentration, higher ammonia removal efficiency and elimination capacity due to its improvement modifications of both raising available oxygen level and abatement of plugging problems by break-up filter biomass clogging. Absence of nitrate removal efficiency and elimination capacity in most time implies that Filter $(C)$ conserves nitratenitrogen in fish wastewater. Acceptable flushing of solids from the filter is serious. Low available dissolved oxygen and plugging are common problems existed in submerged filters, it could be improved with supplemental oxygenation and bubble aeration.

Keywords: Bioremediation, fish, wastewater, modified, aerated, beads, biological filter

\section{INTRODUCTION}

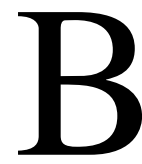
ioremediation is a "treatment that uses naturally occurring organisms to break down hazardous substances into less toxic or non-toxic substances", it is the applications of biotechnology domestic wastewater utilizing living things include plants and animals as agents of degrading pollutants, (Mangunwardoyo et al., 2013). Bioremediation may occurs on its own (natural attenuation or intrinsic bioremediation) or may only effectively occur through the addition of fertilizers, oxygen, etc., that help encourage the growth of the pollutioneating microbes within the medium (biostimulation). Microorganisms used to perform the function of bioremediation are known as bioremediators.

Intensive aquaculture in recirculating systems is rapidly developing, and with it arises the need for reliable treatment systems. To enable reuse of water in these systems, biological treatment is considered the most economically feasible approach, (Van Rijn, 1996). Profitability of recirculating systems depends in part on the ability to manage nutrient wastes. Nitrogenous wastes in these systems can be eliminated through nitrifying and denitrifying biofilters (Van Rijn, et al., 2006).

As the aquaculture industry intensively develops, its environmental impact increases, (Crab et al., 2007). Discharges from aquaculture deteriorate the receiving environment and the need for fishmeal and fish 
oil for fish feed production increases. Rotating biological contactors, trickling filters, bead filters and fluidized sand biofilters are conventionally used in intensive aquaculture systems to remove nitrogen from culture water. Wastewater components can lead to imbalances disrupt aquatic ecosystems and human health, such as the presence of Escherichia coli, and the possible presence of hazardous substances such as elemental N, P, As, Cr, and Se which can lead to poisoning of fish, birds and mammals, (Mangunwardoyo, et al., 2013).

All contaminants aren't easily treated by bioremediation using microorganisms, heavy metals such as cadmium and lead are not readily absorbed or captured by microorganisms. However, Freeman, (2012) suggested that fish bones had some success absorbing lead from contaminated soil. Moreover, bone char has been shown to bioremediate small amounts of cadmium, copper, and zinc, (Xue, 2007). Adam et al., (2015) recommended that the removals of pollutants (nitrate, silicate, chromium and sulphide) from tannery wastewater were studied in batch experiments using marine microalgae.

Nitrification processes have served as an important basis for the development of today's understanding and mathematical models for many wastewater treatment processes (activated sludge, biofilm reactors) and self-purification processes in rivers, (Gullicks, et al., 2011). Nitrifying microorganisms in fixed bed biofilm reactors fed with different nitrite and ammonia concentrations were reported by (ter Haseborg et al., 2010). They detected that an increase in the abundance of Nitrobacter species during high nitrite concentration periods.

Increased popularity of attached-growth wastewater treatment systems (e.g., biological aerated filtration processes-BAF and various hybrids of membrane biological reactors-MBR) has created the need for a rapid and reliable method of characterizing biofilms, (Gullicks et al., 2011 and Delatolla et al., 2008). They added also, that biofilm fixed film systems will continue to have relevance in the treatment of wastewater as technological advances, such as membrane bioreactors and their hybrids, evolve. 
Wide ranges of biofilter types are used to treat dissolved wastes in aquaculture, but the most common include: (a) submerged biofilters, (b) trickling biofilters, (c) rotating biological contactors, (d) pressurized-bead biofilters, (e) fluidized-bed biofilters and (f) mixed bed reactors. Biofilters are still more difficult to control and design than traditional technologies and more fundamental knowledge of the processes that control reactor performance is needed to consolidate biofiltration (Alonso et al., 2000). Biofilter system design consists of two major tasks: (a) sizing the unit (type and volume of packing media) and (b) engineering the physical system (specifying pretreatment equipment, reactor vessel and auxiliary process control equipment) (Skladany et al., 1998 and Devinny et al., 1998).

Submerged biofilters consisted of a bed of media through which the wastewater passes in an upward, or downward direction (to control of hydraulics retention time), media are generally large in size $(5-10 \mathrm{~cm}$ rock, or $2-5 \mathrm{~cm}$ random or structured plastic media) so as to provide large void spaces (Bartali and Wheaton, 1999). Submerged filters captured some of the biological solids but may have problems that result from heavy loading of organic matter coupled with improper solids flushing or underdrain design. Characteristics of the media in a static-media filter ultimately influence the removal of suspended, settleable and dissolved organics as well as the head loss generated and the success of flushing the filter. Media with sufficient voids for use in biofilters could be random media such as uniform crushed rock over $5 \mathrm{~cm}$ in diameter, or plastic media over $2.5 \mathrm{~cm}$ in diameter, or structured media such as plates or tubes that had large voids.

Relationships between nitrification rates and easily accessible process parameters, like bulk phase concentration of TAN, $\mathrm{O}_{2}$, organic matter (COD), nitrite, temperature, $\mathrm{HCO}_{3}{ }^{-}, \mathrm{pH}$ and the hydraulic loading of the trickling filter, are discussed in relation to the design and operation of such filters (Eding et al., 2006). Trickling filter design procedures are presented and one of them, a model describing the nitrification performance of trickling filters by plug-flow characteristics. Redundancy analysis demonstration of the relevance of the temperature to ammonia 
oxidizing was investigated by (Park et al., 2009) and temperature was more significant than salt concentration effects on ammonia-oxidizing bacterial (AOB) community compositions and dynamics in wastewater treatment bioreactors.

You et al., (2009) stated that two major microbial groups are now believed to be involved in ammonia oxidation: chemolithotrophic ammonia-oxidizing bacteria (AOB) and ammonia-oxidizing archaea (AOA). They studied nitrogen removal by AOA, reporting that AOA thrive in many environments, including wastewater treatment systems, and that AOA may outnumber AOB. Wichern et al., (2008) studied optimization of a sequencing batch reactor (SBR) operation treating dairy wastewater with aerobic granular sludge. Their dynamic mathematical model was developed describing COD and nitrogen removal as well as typical biofilm processes such as diffusion or substrate limitation in greater detail. They reported that under different operational conditions average nitrification rates up to $5 \mathrm{~g} \mathrm{~N} /\left(\mathrm{m}^{3} \mathrm{~h}\right)$ and denitrification rates up to $3.7 \mathrm{~g} \mathrm{~N} /\left(\mathrm{m}^{3} \mathrm{~h}\right)$ could be achieved.

Mathematical models are critical to modern environmental biotechnology both in research and in the engineering practice, (Boltz et al., 2009a). Jennings et al. (1976) developed a theoretical model for percent removal of a pure, adsorbable, biodegradable substrate in a submerged biological filter by using the nonlinear expression for the substrate utilization rate. They concluded that the percent removal of substrate was a weak function of biolayer thickness (and thus total cell mass) when the thickness was greater than a rather small limiting value, but was a strong function of particle radius (and thus biolayer surface area).

A model of integrated fixed-film activated sludge (IFAS) and movingbed biofilm reactor (MBBR) systems was developed by (Boltz et al., 2009b). Their model was based on theoretical considerations that include: simultaneous diffusion and Monod-type reaction kinetics inside the biofilm; competition between aerobic autotrophic nitrifies, nonmethanol-degrading facultative heterotrophs, methanol-degrading heterotrophs; slowly biodegradable chemical oxygen demand; and inert biomass for substrate (when appropriate) and space inside the biofilm; 
and biofilm and suspended biomass compartments, which compete for both the electron donor and electron acceptor. The model assumed identical reaction kinetics for suspended biomass and biofilm bacteria.

The impact of organic carbon on the performance of a high rate nitrifying trickling filter as a pre-treatment process to remove low concentrations of ammonia from polluted surface water was investigated by (van den Akker et al., 2008 and van den Akker et al., 2010a). When organic load increased beyond 0.75 to $2.1 \mathrm{~g}$ sBOD $5 / \mathrm{m}^{2} \mathrm{~d}$, a linear decline in nitrification from $70 \%$ down to $15 \%$ was observed in 8 to10 d. In addition, van den Akker et al., (2010b) reported on the application of high rate nitrifying trickling filters to remove low concentrations (approximately $3 \mathrm{mg} / \mathrm{L}$ ) of ammonia from reclaimed municipal wastewater. Nitrification was impeded by high organic carbon loads and aquatic snails, which consumed much of the active biomass.

Nitrogen dynamics and removal in a horizontal flow biofilm reactor (HFBR), step-feed wastewater treatment process was investigated by (Clifford et al., 2010). They reported that significant simultaneous nitrification and denitrification in the nitrifying zone. The results can be used to optimize HFBR reactor design and provide an alternative, low maintenance, economically efficient system for carbon and nitrogen removal for low flow wastewater discharges.

Tal et al., (2003) stated that beads with a high organic load exhibited a lower nitrification rate $\left(25 \mathrm{mg} \mathrm{NH} \mathrm{N}_{3}-\mathrm{N} / \mathrm{m}^{2} / \mathrm{h}\right)$ than low organic load beads (31.5 $\mathrm{mg} \mathrm{NH} \mathrm{NH}_{3}-\mathrm{N} / \mathrm{m}^{2} / \mathrm{h}$ ) as well as the ability to carry out denitrification and anammox processes. They found that moving bed bioreactor has the capability to serve as a platform for mediating desired anoxic processes such as denitrification and anammox. Breisha, (2010) reported that factors affecting the nitrogen removal efficiency included temperature, dissolved oxygen, nitrate concentration, salinity, $\mathrm{pH}$ or the free ammonia concentration.

Removal efficiency and elimination capacity have been used to describe the performance of biofilter by many researchers (Swanson and Loehr, 1997; Abumaizar and Kocher, 1998; Devinny et al., 1998; Seedorf and Hartung, 1999; Okuno and Hirai, 2000 and Selvi and Artuz, 
2000). Devinny et al., (1998) defined removal efficiency (RE) as the fraction of the contaminant removed by the biofilter, expressed as a percentage. They also, defined elimination capacity (EC) as the mass of contaminant degraded per unit volume of the filter medium per unit time.

The scope of research work is to get treated water suitable for other purposes such as re-farming out again and used to irrigate farms, especially vegetables and used in the cultivation of surfaces so that it works to reduce the burden on the Nile waters and contribute to the bridging part of the gap water poverty in Egypt.

\section{MATERIAL AND METHODS}

The present research work was performed at Bio-Engineering Lab, Agric. Eng. Dept., Fac. of Agric., Cairo Univ., through May and June, 2012. The experiments used two types of filters that are both working on the filtration of water, organic and inorganic materials (suspended or dissolved) in water. Fig.(1) illustrates whole experimental aquarium with both biofilters. The filters differed in filtration element, first filter (A) contains a spongy filter element, and the other (C) contains plastic granules (beads). Samples from both are taken and analyzed to compare the final results and measuring filtration efficiency for each filter.

\section{Experimental Design Steps}

Experiments were conducted in an aquarium with dimensions of (120 cm- length $-60 \mathrm{~cm}$ width $-80 \mathrm{~cm}$ high- with water high of $40 \mathrm{~cm}$ and basin volume of $0.3 \mathrm{~m}^{3}$, which is equivalent to 300 liters) with high pressure resistance Spanish glass thickness of $10 \mathrm{~mm}$ are designed and tested. Fill the basin with tap water to a height of $40 \mathrm{~cm}$ and thus the volume of water has become in the pelvis ( 0.3 cubic meters), which is equivalent to (300 liters).

Aquarium filters come in several different forms, from under-gravel filter trays, internal power-head filters and external "Sump" filters. Filter (A) Spongy, Unee ${ }^{\circledR}$ Internal Submersible Filter, (Hidom 1000 LPH Aquarium Fish Tank Internal Filter Pump AP-1350L) (207 x 78 x 52 $\mathrm{mm}),(220-240 \mathrm{v}, 50 / 60 \mathrm{~Hz}, 18 \mathrm{~W}, 200 \mathrm{~L}$ Aquarium size and Q. Max of $1000 \mathrm{~L} / \mathrm{h}$ ) and Fitted with 3 pin UK plug and had a cable of 1.4 meters 
length. Filter (A), was supplied with high-quality replaceable filter sponge, complete with suctions caps for attaching to the side of fish tank. Venturi air line attachment, twin outlets powerhead with blanking plug if only one outlet required.

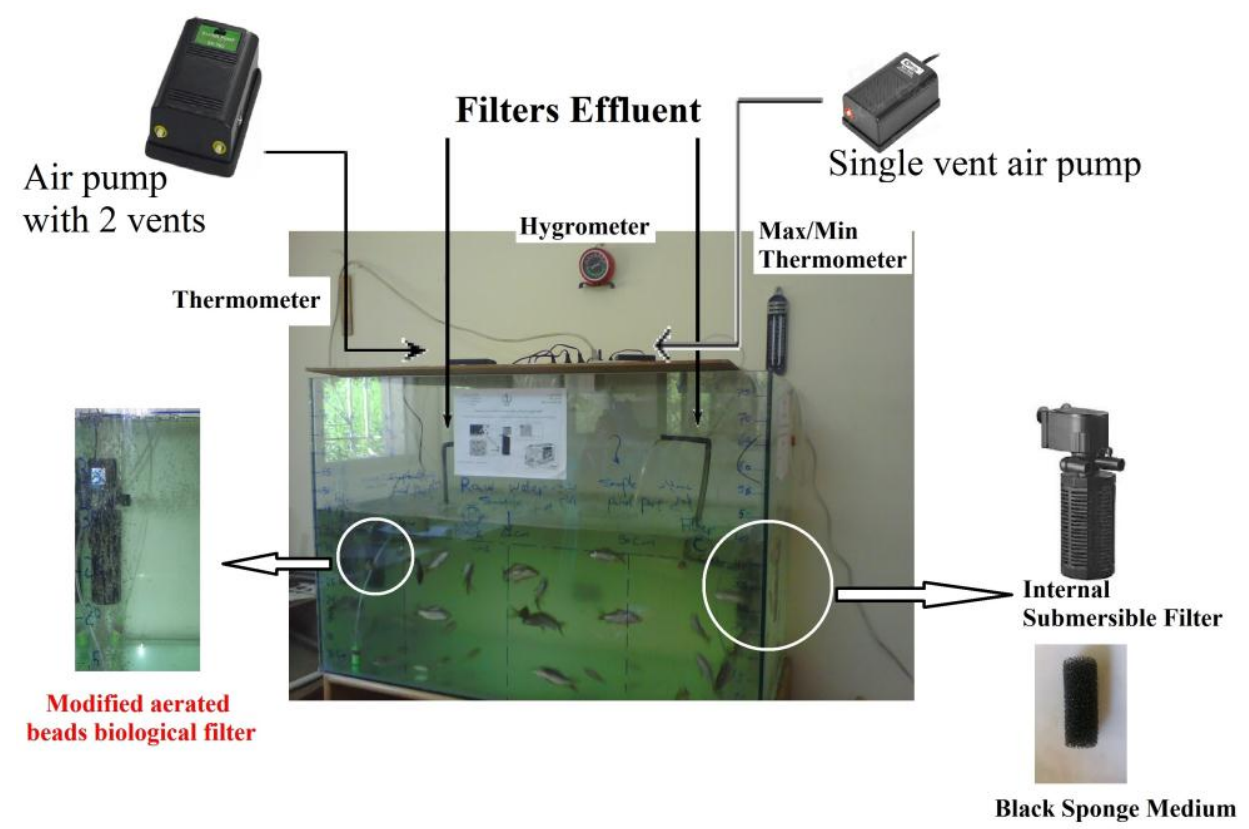

Fig.(1). Whole experimental aquarium with both biofilters.

Its black sponge medium (Approx. size: Height $116 \mathrm{~mm}$ x Diameter $53 \mathrm{~mm}$ ) is provided by a hose of polyethylene in the middle that perforated at $2 \mathrm{~cm}$ distances for the passage of a stream of air inside by plugging the other end of the hose. Plastic air pump, (SILVER LAKE, SP-780), (220/240V, 50Hz, 220V 240V/50Hz, 5W and output air flow rate of $3.5 \mathrm{~L} / \mathrm{min}$ ) with 2 vents (air outlet) and cord length of $63 \mathrm{~cm}$.

The filtering element inside second filter (C) Crystal was plastic granules (beads) with diameters ranging from (0.7 to 0.8 , average of 0.75$)$ and an average calculated porosity of $50 \%$. In the middle, it is also had a transparent hose of polyethylene perforated at equal distances every $2 \mathrm{~cm}$ for to passage of the air stream and the other side had, also fixed air pump connector outlet. 
Filters were coupled with 4 cylindrical air publishers, which are working to make the ratio of oxygen within the fixed tube with continuous stirring of the water (E5LS HX-508 Oxygen Increasing Air Pump w/ 2-RoundPin Plug for Fish Tank - Black Plastic + steel (E5LS HX-508) Suitable for $50 \mathrm{~cm}$ deep water tank; to maintain the water quality of the fish tank, increase the oxygen for fish; EU plug with $60 \mathrm{~cm}$ cable ( AC 220 240V ؛ $50 / 60 \mathrm{~Hz} \leq 2.5 \mathrm{~W} \leq$ Air displacement of $2.5 \mathrm{~L} / \mathrm{min}$ ).

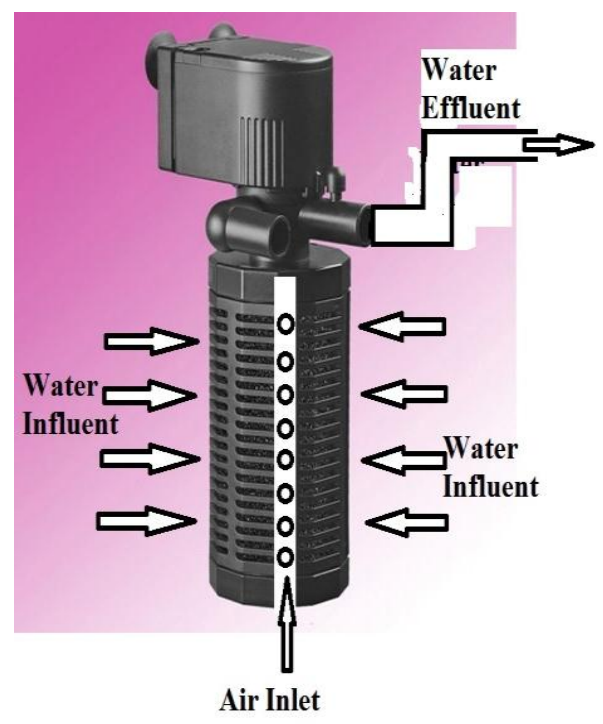

Filter (A) Spongy

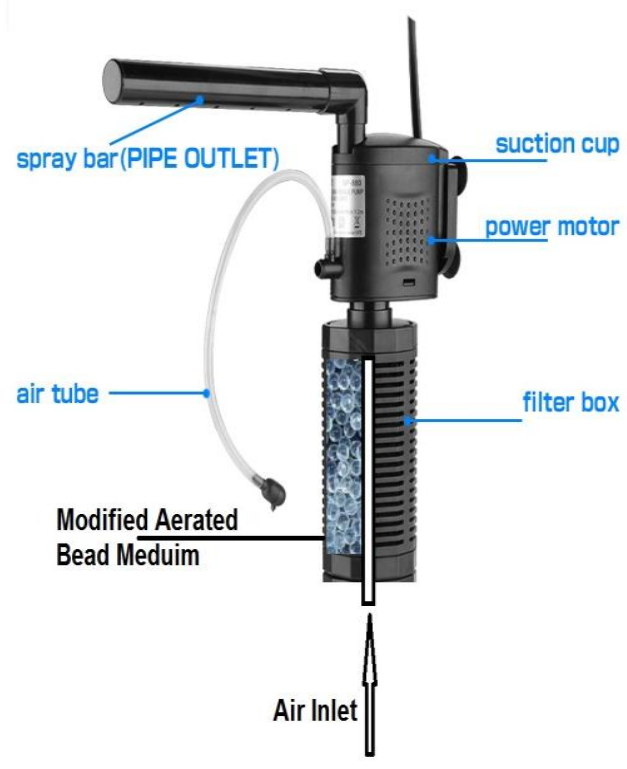

Filter (C) Crystal

Fig.(2). Schematic diagram for Filter (A) Spongy and Filter (C) Crystal

Each filter was provided with ( $\mathrm{Z}$ shape tube to take a sample of water that has been filtered from both Filter (A) and (C) and before re-turn water to the basin. It was compared to the proportion of ammonia and nitrates in each of the filter (A) and filter (C) and untreated water sample (B). Temperature, (av. Min \& Max.) and relative humidity on a daily basis throughout the trial (weeks) were recorded. Test samples were taken every three days to allow for the modified filter change all aquarium water.

Nile Tilapia (Oreochromis niloticus) fingerlings with a ranged weight of (7 g -20 g) average (12.167 g) and a Silver Carp (Hypophthalmichthys 
morlitrix) thickness of (15.8 g - $27.8 \mathrm{~g}$ ), average (20.53 g), were used. Feeding fingerlings of tilapia and carp fry on a bush grille of animal protein. Chemical analysis of water sample, for available nitrogen, Ammonium-N, $\mathrm{NH}_{4}{ }^{-}$and available nitrogen, Nitrate- $\mathrm{N}, \mathrm{NO}_{3}{ }^{-} \mathrm{N}$, of water samples was performed at Unit of Soil water and Environment., Analysis and Studies Component., Soils, Water \& Environment Res. Ins. (S.W.E.R.I), Agricultural Research Center (ARC), Ministry of Agriculture \& Land Reclamation.

\section{Volume of packing material and contact time}

The critical step in sizing a biofilter bed is to calculate the empty bed residence time (EBRT) (Swanson and Loehr, 1997; and Skladany et al., 1998) and the true residence time (retention time) (Devinny et al., 1998):

$$
\begin{aligned}
& \text { EBRT }=\frac{\mathrm{V}_{\mathrm{f}}}{\mathrm{Q}} \\
& \tau=\frac{V_{f} \times \varepsilon}{Q} \times 3600
\end{aligned}
$$

Where:

$$
\begin{array}{ll}
V_{f} & \text { is biofilter media volume }\left(\mathrm{m}^{3}\right) . \\
Q & \text { is air flow rate }\left(\mathrm{m}^{3} / \mathrm{h}\right) . \\
\tau & \text { is true residence (retention) time (second). } \\
\varepsilon & \text { is porosity (volume of void space/volume of filter material). }
\end{array}
$$

\section{Removal Efficiency and Elimination Capacity}

Removal efficiency (RE) and elimination capacity (EC) can be calculated by using the following equations (Swanson and Loehr, 1997):

$$
\begin{aligned}
& R E=\left[\frac{C_{i}-C_{e}}{C_{i}}\right] \times 100 \\
& E C=\frac{\left(C_{i}-C_{e}\right) \times Q}{V_{f}} \times 10^{-3}
\end{aligned}
$$

Where:
$\mathrm{C}_{\mathrm{i}}$ is the influent concentration $\left(\mathrm{g} / \mathrm{m}^{3}\right)$.
$\mathrm{C}_{\mathrm{e}}$ is the effluent concentration $\left(\mathrm{g} / \mathrm{m}^{3}\right)$. 


\section{RESULTS AND DISCUSSION}

Conversion from one nitrogen form to another was usually resulted by bacterial processes, mineralization (ammonification), the process of converting organic nitrogen to ammonium ions $\left(\mathrm{NH}_{4}{ }^{+)}\right.$via degradation of proteins, amino sugars and nucleic acids. Ammonium (the major nitrogen form used by plants), is resistant to leaching because it is absorbed onto the cation-exchange complex in the soil. Table (1), illustrates chemical analysis of initial water sample at start of experiment. That shows that EC of $1.23 \mathrm{mmohs} / \mathrm{cm}, \mathrm{pH}$ of 7.4 and general laboratory comment stated that water sample was moderately suitable for irrigation.

Nitrate, end product of the nitrification process; colorless, odorless, and tasteless compound; can be expressed as either $\mathrm{NO}_{3}{ }^{-}$(nitrate) or $\mathrm{NO}_{3}-\mathrm{N}$ (nitrate-nitrogen). Nitrate form of $\mathrm{N}$ is soluble in water, Table (2) demonstrate available nitrogen, Ammonium- $\mathrm{N}, \mathrm{NH}_{4}^{-}$, and available nitrogen, Nitrate- $\mathrm{N}, \mathrm{NO}_{3}{ }^{-} \mathrm{N}, \mathrm{mg} / \mathrm{L}, \mathrm{mg} / \mathrm{L}$, of water samples.

Table (1). The chemical analysis of water sample.

\begin{tabular}{cccc}
\hline Parameter & Value & & \\
\hline $\mathrm{EC}($ mmohs $/ \mathrm{cm})$ & 1.23 & & \\
$\mathrm{ppm}$ & 787.0 & & \\
$\mathrm{pH}$ & 7.4 & & \\
\hline Soluble Anions $($ meq./L) & Soluble Cations $($ meq./L) \\
\hline $\mathrm{CO}_{3}{ }^{-}$ & -- & $\mathrm{Ca}^{++}$ & 1.78 \\
$\mathrm{HCO}_{3}{ }^{-}$ & 1.16 & $\mathrm{Mg}^{++}$ & 0.87 \\
$\mathrm{CT}^{-}$ & 7.50 & $\mathrm{Na}^{++}$ & 9.44 \\
$\mathrm{SO}_{4}{ }^{++}$ & 3.68 & $\mathrm{~K}^{+}$ & 0.25 \\
& & $\mathrm{RSC}^{+}$ & -- \\
& & $\mathrm{SAR}$ & 8.21 \\
\hline
\end{tabular}

Laboratory Comment: This water sample is moderately suitable for irrigation. 
Table (2). The available nitrogen, Ammonium-N, $\mathrm{NH}_{4}{ }^{-}$, and available nitrogen, Nitrate- $\mathrm{N}^{\mathrm{NO}_{3}}{ }^{-} \mathrm{N}, \mathrm{mg} / \mathrm{L}$, of water samples.

\begin{tabular}{ccccccc}
\hline \multirow{2}{*}{$\begin{array}{c}\text { Sample } \\
\text { No. }\end{array}$} & \multicolumn{3}{c}{ Available nitrogen, } & \multicolumn{3}{c}{$\begin{array}{c}\text { Available nitrogen, Nitrate- } \\
\mathrm{N}, \mathrm{NO}_{3}^{-} \mathrm{N}, \mathrm{mg} / \mathrm{L}\end{array}$} \\
\cline { 2 - 7 } & Blank & $\begin{array}{c}\text { Filter } \\
(\mathbf{A})\end{array}$ & $\begin{array}{c}\text { Filter } \\
(\mathbf{C})\end{array}$ & Blank & $\begin{array}{c}\text { Filter } \\
(\mathbf{A})\end{array}$ & $\begin{array}{c}\text { Filter } \\
(\mathbf{C})\end{array}$ \\
\hline 1. & 5.59 & 6.56 & 6.56 & 0.00 & 0.88 & 0.44 \\
2. & 10.94 & 10.50 & 15.31 & 1.31 & 0.88 & 1.31 \\
3. & 13.56 & 12.69 & 14.00 & 0.88 & 2.63 & 1.31 \\
4. & 183.75 & 170.63 & 161.88 & 8.75 & 21.88 & 43.75 \\
5. & 2.63 & 2.63 & 1.31 & 26.69 & 27.13 & 27.13 \\
6. & 24.50 & 24.44 & 29.75 & 1.75 & 1.31 & 2.63 \\
7. & 10.94 & 3.94 & 2.38 & 27.13 & 33.25 & 39.38 \\
8. & 4.81 & 4.38 & 6.56 & 42.09 & 39.38 & 36.31 \\
9. & 7.00 & 6.56 & 7.88 & 45.5 & 45.94 & 44.19 \\
10. & 22.31 & 13.13 & 23.63 & 38.94 & 45.94 & 39.38 \\
\hline
\end{tabular}

Fig.(2), shows the available nitrogen, Ammonium- $\mathrm{N}, \mathrm{NH}_{4}^{-}, \mathrm{mg} / \mathrm{L}$, of blank, Filter (A) and filter (C) water samples. Ammonia concentration of blank water increased gradually from $5.59 \mathrm{mg} / \mathrm{L}$ at experimental start to $183.75 \mathrm{mg} / \mathrm{L}$ after 11 days then decreased to about $2.63 \mathrm{mg} / \mathrm{L}$ due to the action of biofiltration, it still remaining at a level under $25 \mathrm{mg} / \mathrm{L}$ (24.50) till the end of experiment. Ammonia concentrations for both biofilters, A and $\mathrm{C}$, had same trend but after 11 days ammonia concentrations decreased to about $2.63 \mathrm{mg} / \mathrm{L}$ for filter A and to 1.31 for filter $\mathrm{C}$ that was due to reverse cleaning of biofilter media to control a clogging that was happened by biomass accumulation.

This result is agree with that of (Bartali and Wheaton, 1999), which reported that solids may accumulate in static filter beds based on both physical and biological mechanisms. Physically, suspended or settleable solids may be entrapped within the filter voids because of settling, sieving, and interception. Biologically, cell mass will be produced by the microbial metabolism of substrates (primarily organics and ammonia) passing through the filter, both on the surface of the media and in the voids between the media. Cell mass resulting from nitrifying is desirable 
but cell mass resulting from heterotrophic organisms, although required to some extent, may increase plugging problems in static-media filters. Therefore, conditions that allow the filter to plug or to exhaust the dissolved oxygen that is available in the water must been avoided.

Moreover, experimental results are agree with (van den Akker et al., 2008 and van den Akker et al., 2010a), that reported that when organic load increased beyond 0.75 to $2.1 \mathrm{~g} \mathrm{sBOD} / \mathrm{m}^{2} \mathrm{~d}$, a linear decline in nitrification from $70 \%$ down to $15 \%$ was observed in 8 to10 d. In addition, are agree with van den Akker et al., (2010b) which reported that the application of high rate nitrifying trickling filters to remove low concentrations (approximately $3 \mathrm{mg} / \mathrm{L}$ ) of ammonia from reclaimed municipal wastewater. Nitrification was impeded by high organic carbon loads and aquatic snails, which consumed much of the active biomass. Also, are agree with Tal et al., (2003) which stated that beads with a high organic load exhibited a lower nitrification rate $\left(25 \mathrm{mg} \mathrm{NH} \mathrm{N}_{3}-\mathrm{N} / \mathrm{m}^{2} / \mathrm{h}\right.$ ) than low organic load beads $\left(31.5 \mathrm{mg} \mathrm{NH}-\mathrm{N} / \mathrm{m}^{2} / \mathrm{h}\right)$.

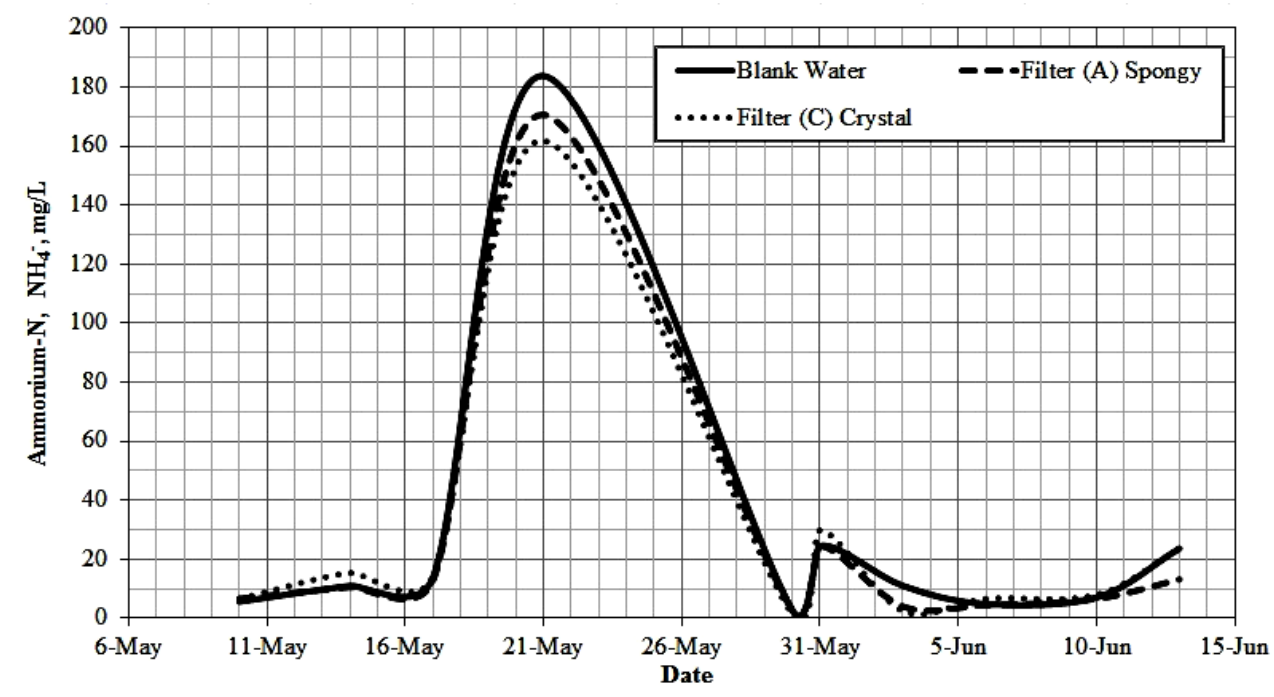

Fig.(2). The available nitrogen, Ammonium-N, $\mathrm{NH}_{4}{ }^{-}, \mathrm{mg} / \mathrm{L}$, of water samples. Acceptable flushing of solids from the filter is serious. Solids sometimes had to be flushed from the submerged biofilter media voids daily by reversed-flow flushing and less often by air scour coupled with reversedflow flushing. Bartali and Wheaton, 1999, stated that a drainable filter, 
a properly designed underdrain, a high velocity of a reversed flow of water and a means for air scouring are all required for good solids flushing. Underdrains must provide a support for the media and force the water, during regular operation or during flushing, to flow uniformly through the bed.

Two submerged filters advanced modifications have been developed to reduce two public operational problems: low available dissolved oxygen and plugging problems. Operating problems could be improved with supplemental oxygenation and bubble aeration. Both modifications raised the level of available oxygen and helps to break-up clogging to a variable extent. Strong aeration strips off thick growth of biofilm, thus helped to prevent biofilm growth from clogging the pores in the filter media. These aerated biofilters have been effectively used to maintain good water quality in re-circulating systems (Bartali and Wheaton, 1999).

Nitrification, the biological process of converting ammonium ions $\left(\mathrm{NH}_{4}{ }^{+}\right)$ to nitrite $\left(\mathrm{NO}_{2}{ }^{-}\right)$and then to nitrate $\left(\mathrm{NO}_{3}{ }^{-}\right)$, oxidative reaction and was occurred by special types of microorganisms convert ammonium ion $\left(\mathrm{NH}_{4}{ }^{+}\right)$into nitrate in a two-step. Two different groups of nitrifying bacteria (autotrophy and obligate aerobes) are needed for complete nitrification, Nitrosomonas $\boldsymbol{S p}$ convert ammonium ion $\left(\mathrm{NH}_{4}{ }^{+}\right)$into nitrite $\left(\mathrm{NO}_{2}{ }^{-}\right)$, and then Nitrobacte $\boldsymbol{S p}$ converted the nitrite $\left(\mathrm{NO}_{2}{ }^{-}\right)$into nitrate $\left(\mathrm{NO}_{3}{ }^{-}\right)$, nitrite is normally a transitory phase in the nitrification process, Fig.(3), illustrates the available nitrogen, Nitrate- $\mathrm{N}, \mathrm{NO}_{3}{ }^{-} \mathrm{N}, \mathrm{mg} / \mathrm{L}$, of blank, Filter (A) and filter (C) water samples.

Biofiltration process started-up, nitrate concentration of blank water increased gradually from $0.00 \mathrm{mg} / \mathrm{L}$ at experimental start to $26.69 \mathrm{mg} / \mathrm{L}$ after 14 days then decreased to about 1.75 , but also, it increased gradually again to a level of $45.5 \mathrm{mg} / \mathrm{L}$ after 27 days, due to biofiltration action. Increased loading can affect the capacity of the biofilter to complete the two-step bacterial conversion of ammonia to nitrate, due to increased competition for space and oxygen among heterotrophic organisms and Nitrosomonas and Nitrobacter.

Same trend of nitrate concentration of filter (A) and (C) can be observed, nitrate concentration increased progressively from $0.88 \mathrm{mg} / \mathrm{L}$ to 21.88 
$\mathrm{mg} / \mathrm{L}$ for filter (A) and from $0.44 \mathrm{mg} / \mathrm{L}$ to $43.75 \mathrm{mg} / \mathrm{L}$ for filter (C) respectively, after 11 days from experiment beginning, acclimation periods for the microbial population may take a lot of time. Filter (C) showed superiority in nitrate concentration which is mean more improvement of using a modified aerated beads filter over other more conventional one.

Nitrate concentrations for both biofilters, A and C decreased gradually after 11 days to a level of 1.31 and $2.63 \mathrm{mg} / \mathrm{L}$ respectively, filter $(\mathrm{C})$ is still superior, when loading rate is increased, space and oxygen become limited. Nitrobacter need the produced nitrite by Nitrosomonas and tend to be located towards the outlet end of the biofilter,(Bartali and Wheaton, 1999), Nitrobacter are commonly displaced firstly because they are the last in the line of microbial consumers. Nitrosomonas may also be displaced or damage from oxygen limiting conditions, that cause a reduction in the relative amount of Nitrobacter compared with Nitrosomonas and will cause the nitrite concentration through biofilter medium to increase, which can become poisonous inside water recirculating system. Finally, nitrate concentrations increased to 45.94 and $39.38 \mathrm{mg} / \mathrm{L}$ for filters (A) and (C) respectively, which was occurred due to reverse washing of biofilter media to control a clogging that was happened by biomass accumulation.

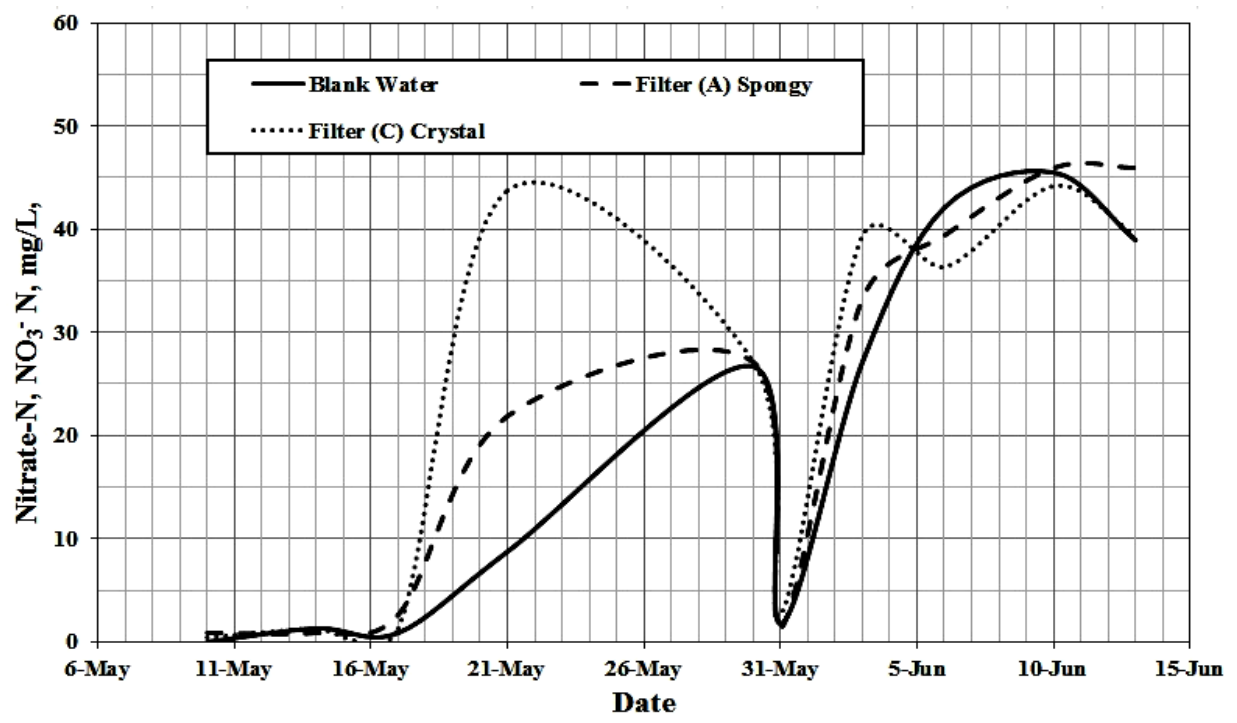

Fig.(3) . The available nitrogen, Nitrate- $\mathrm{N}, \mathrm{NO}_{3}{ }^{-} \mathrm{N}, \mathrm{mg} / \mathrm{L}$, of water samples. 
Removal efficiencies and elimination capacities for ammonia and nitrate compounds treated with both biofilters (A and C) are demonstrated in Table (3). Ammonia could be, biologically, removed with a removal efficiencies ranged from 4.02 to $63.99 \%$ for filter (A) and from 11.9 to $78.24 \%$ for filter (C), elimination capacities of ammonia removal were fluctuated between 2.28 and $67.98 \mathrm{~g} / \mathrm{L}$. $\mathrm{h}$ for filter (A) and between 6.84 and $113.32 \mathrm{~g} / \mathrm{L}$. h for filter (C), respectively. Filter (C), a modified aerated beads biological filter, shows a higher removal efficiency and elimination capacity due to its improvement modifications of both raising the level of available oxygen and abatement of plugging problems by break-up filter biomass clogging.

Table (3). Removal Efficiency and Elimination Capacity for available nitrogen, Ammonium- $\mathrm{N}, \mathrm{NH}_{4}^{-}$, and available nitrogen, Nitrate- $\mathrm{N}, \mathrm{NO}_{3}{ }^{-} \mathrm{N}, \mathrm{mg} / \mathrm{L}$, of water samples.

\begin{tabular}{|c|c|c|c|c|c|c|c|c|}
\hline \multirow{3}{*}{$\begin{array}{c}\text { Sample } \\
\text { No. }\end{array}$} & \multicolumn{4}{|c|}{$\begin{array}{c}\text { Available nitrogen, } \\
\text { Ammonium-N, } \mathrm{NH}_{4}^{-}, \mathrm{mg} / \mathrm{L}\end{array}$} & \multicolumn{4}{|c|}{$\begin{array}{c}\text { Available nitrogen, } \\
\text { Nitrate-N, } \mathrm{NO}_{3}^{-} \mathrm{N}, \mathrm{mg} / \mathrm{L}\end{array}$} \\
\hline & \multicolumn{2}{|c|}{ Filter (A) } & \multicolumn{2}{|c|}{ Filter (C) } & \multicolumn{2}{|c|}{ Filter (A) } & \multicolumn{2}{|c|}{ Filter (C) } \\
\hline & $\underset{\%}{\mathrm{RE},}$ & $\begin{array}{c}\text { EC, } \\
\text { g/L. h }\end{array}$ & $\begin{array}{c}\text { RE, } \\
\%\end{array}$ & $\begin{array}{c}\text { EC, } \\
\text { g/L. h }\end{array}$ & $\underset{\%}{\mathrm{RE}}$ & $\begin{array}{c}\text { EC, } \\
\text { g/L. h }\end{array}$ & $\underset{\%}{\mathrm{RE},}$ & $\begin{array}{c}\text { EC, } \\
\text { g/L. h }\end{array}$ \\
\hline 1 & -- & -- & -- & -- & -- & -- & -- & -- \\
\hline 2 & 4.02 & 2.28 & -- & -- & 32.82 & 2.23 & -- & -- \\
\hline 3 & 6.42 & 4.51 & -- & -- & -- & -- & -- & -- \\
\hline 4 & 7.14 & 67.98 & 11.90 & 113.32 & -- & -- & -- & -- \\
\hline 5 & 0.00 & -- & 50.19 & 6.84 & -- & -- & -- & -- \\
\hline 6 & 0.24 & 0.31 & -- & -- & 25.14 & 2.28 & -- & -- \\
\hline 7 & 63.99 & 36.27 & 78.24 & 33.99 & -- & -- & -- & -- \\
\hline 8 & 8.94 & 2.23 & -- & -- & 6.44 & 14.04 & 13.73 & 29.95 \\
\hline 9 & 6.29 & 2.28 & -- & -- & -- & -- & 2.88 & 6.79 \\
\hline 10 & 41.15 & 47.56 & -- & -- & -- & -- & -- & -- \\
\hline
\end{tabular}

Nitrate removal efficiencies ranged from 6.44 to $32.82 \%$ for filter (A) and from 2.88 to $13.73 \%$ for filter (C), elimination capacities of nitrate 
removal were oscillated between 2.23 and $14.04 \mathrm{~g} / \mathrm{L}$. h for filter (A) and between 6.79 and 29.95.32 g/L. h for filter (C) respectively. Absence of nitrate removal efficiency and, subsequently, elimination capacity in most time imply that Filter (C), conserves nitrate-nitrogen in fish wastewater that is mean that more useful nitrogen fixing.

Table (4) illustrates water plug weight (g), time interval (s), empty bed residence time (EBRT), (s) and true residence time (retention time), (s) for Filter (A) Spongy and Filter (C) Crystal, respectively.

Table (4). Water Plug Weight (g), Time Interval (s), Empty bed residence time (EBRT), (s) and True residence time (retention time), (s) for Filter (A) Spongy and Filter (C) Crystal.

\begin{tabular}{|c|c|c|c|c|}
\hline \multirow[b]{2}{*}{ No } & \multicolumn{2}{|c|}{ Filter (A) Spongy } & \multicolumn{2}{|c|}{ Filter (C) Crystal } \\
\hline & $\begin{array}{l}\text { Water Plug } \\
\text { Weight (g) }\end{array}$ & $\begin{array}{c}\text { Time } \\
\text { Interval (s) }\end{array}$ & $\begin{array}{l}\text { Water Plug } \\
\text { Weight (g) }\end{array}$ & $\begin{array}{c}\text { Time } \\
\text { Interval (s) }\end{array}$ \\
\hline & 45.74 & 16.24 & 21.83 & 6.57 \\
\hline & 43.87 & 14.22 & 22.95 & 8.01 \\
\hline & 38.88 & 17.64 & 20.96 & 12.10 \\
\hline & 7.17 & 14.85 & 43.39 & 12.56 \\
\hline & 12.47 & 17.12 & 25.40 & 6.87 \\
\hline & 37.51 & 14.78 & 20.20 & 6.21 \\
\hline & 27.46 & 34.93 & 19.51 & 9.03 \\
\hline & 39.76 & 28.22 & 25.87 & 6.94 \\
\hline & 37.96 & 11.57 & 20.53 & 7.09 \\
\hline & 36.52 & 16.20 & 22.21 & 7.48 \\
\hline & 43.91 & 15.81 & 25.99 & 6.52 \\
\hline & 11.23 & 12.69 & 23.13 & 9.70 \\
\hline & 36.62 & 13.37 & 23.19 & 6.01 \\
\hline & 34.66 & 15.88 & 18.74 & 5.76 \\
\hline & 40.14 & 16.31 & 39.11 & 12.57 \\
\hline Av. & 32.926 & 17.32 & 24.867 & 12.57 \\
\hline \multicolumn{3}{|c|}{ Filter (A) Spongy } & \multicolumn{2}{|c|}{ Filter (C) Crystal } \\
\hline \multicolumn{2}{|c|}{$\begin{array}{l}\text { Empty bed } \\
\text { residence time } \\
(\text { EBRT), (s) }\end{array}$} & $\begin{array}{l}\text { True residence } \\
\text { time (retention } \\
\text { time), (s) }\end{array}$ & $\begin{array}{l}\text { Empty bed } \\
\text { esidence time } \\
\text { (EBRT), (s) }\end{array}$ & $\begin{array}{l}\text { Ttrue residence } \\
\text { time (retention } \\
\text { time), (s) }\end{array}$ \\
\hline \multicolumn{2}{|c|}{387} & 193 & 330 & 165 \\
\hline
\end{tabular}


Filter (A), had a mean water plug weight of $32.926 \mathrm{~g}$ with average time interval of $17.32 \mathrm{~s}$, empty bed residence time (EBRT) of $387 \mathrm{~s}$ and true residence time (retention time) of $193 \mathrm{~s}$, while Filter (C) that had a $24.867 \mathrm{~g}$ of water plug weight and $12.57 \mathrm{~s}$ as a time interval between plugs, empty bed residence time (EBRT) of $330 \mathrm{~s}$ and true residence time (retention time) of $165 \mathrm{~s}$. These results are agreed with common range for most biofilters residence time $(60-120$ seconds) Selvi and Artuz (2000). While longer residence times produce higher efficiencies, the design must minimize residence time to allow the biofilter to accommodate larger flow rates.

Table (5) illustrates performance parameters date for fish at starting and finishing experimental period, it represents that Nile Tilapia (Oreochromis niloticus) has a growth rate of $3.317 \mathrm{~g}$ (with growth ratio of $27.26 \%$ and mortality ratio of $32 \%$ ) whereas, the growth rate of $15.467 \mathrm{~g}$ (with growth ratio of $42.96 \%$ and mortality ratio of $24 \%$ ) is observed for Silver Carp (Hypophthalmichthys morlitrix). Silver carp had a superior performance data comparing with Nile Tilapia, its superiority due to its tolerate to rearing environmental conditions and its higher initial body weight and age. Final COD was recorded as $25 \mathrm{mg} / \mathrm{L}$, and final BOD was $00 \mathrm{mg} / \mathrm{L}$ which is mean that abatement of nitrogen, biologically, can be achieved using any of tested filters that were used under current experimental conditions

Table (5). Fish performance date at starting and finishing experimental period.

\begin{tabular}{lcc}
\hline \multirow{2}{*}{ Parameter } & \multicolumn{2}{c}{ Fish Type } \\
\cline { 2 - 3 } & $\begin{array}{c}\text { Nile Tilapia } \\
\text { (Oreochromis niloticus })\end{array}$ & $\begin{array}{c}\text { Silver Carp } \\
\text { Hypophthalmichthys } \\
\text { morlitrix })\end{array}$ \\
\hline Av. Initial Weight, g & $\mathbf{8 . 8 5 0}$ & $\mathbf{2 0 . 5 3 3}$ \\
Av. Final Weight, g & $\mathbf{1 2 . 1 6 7}$ & $\mathbf{3 6 . 0 0 0}$ \\
Growth Rate, g & $\mathbf{3 . 3 1 7}$ & $\mathbf{1 5 . 4 6 7}$ \\
Growth Ratio \% & $\mathbf{2 7 . 2 6}$ & $\mathbf{4 2 . 9 6}$ \\
Initial Fish Number,-- & $\mathbf{2 5}$ & $\mathbf{2 5}$ \\
Final Fish Number,-- & $\mathbf{1 7}$ & $\mathbf{1 9}$ \\
Fish Number Difference,- & $\mathbf{8}$ & $\mathbf{6}$ \\
Survival, (\%) (Mortality & $\mathbf{6 8}(\mathbf{3 2})$ & $\mathbf{7 6}(\mathbf{2 4})$ \\
ratio, \%) & &
\end{tabular}




\section{CONCLUSION}

Modified aerated beads biological filter was used and examined as a fish wastewater bioremediation technique, it can conclude that:

- Filter (A), Spongy and filter (C), Crystal were used to clean fish wastewater of debris and suspended particles, remove ammonia and nitrites and aerate the water.

- Their main function is to bring microorganisms (live in a thin layer of moisture ;the biofilm; which surrounds the particles that make up the filter media) into contact with pollutants contained in a wastewater stream, filter material, which is the breeding ground for the microorganisms and pollutants are absorbed into the filter media.

- Filter (C) showed superiority in nitrate concentration which is mean more improvement of using a modified aerated beads filter over other more conventional one.

- Acceptable flushing of solids from the filter is serious. Low available dissolved oxygen and plugging are common problems existed in submerged filters, it could be improved with supplemental oxygenation and bubble aeration.

\section{REFERENCES}

Abumaizar, R.J. and Kocher, W. (1998). Biofiltration of BTEX contaminated air streams using compost-activated carbon filter media. Journal of Hazardous Materials.60 (2): 111-126.

Adam, S. ; Kumar, P.S.; Santhanam, P.; , Kumar, S. D. and Prabhavathi, P. (2015). Bioremediation of Tannery Wastewater Using Immobilized Marine Microalga Tetraselmis sp.: Experimental Studies and Pseudo-Second Order Kinetics. Journal of Marine Biology \& Oceanography, 4:1.

Bartali, E. and Wheaton, F. (1999). Handbook of Agricultural Engineering. Volume II. Animal Production \& Aquaculutral Engineering. The American Society of Agricultural Engineers. 2950 Niles Roads, St. Joseph, Michigan 49085-9659. USA. http: llasea. org/. 
Boltz, J.P.; Johnson, B.R.; Daigger, G.T. and Sandino, J. (2009b). Modeling integrated fixed-film activated sludge and moving-bed biofilm reactor systems I: Mathematical treatment and model development. Water Environ. Res., 81: 555-575.

Boltz, J.P.; Morgenroth, E. and Sen, D. (2009a). Mathematical modelling of biofilms and biofilm reactors for engineering design. Water Sci. Technol., 62: 1821-1836.

Breisha, G. B. (2010). Bio-removal of nitrogen from waste water-A review. Nature and Science. 8 (12): 210-228.

Clifford, E.; Nielsen, M.; Sorensen, K. and Rodgers, M. (2010). Nitrogen dynamics and removal in a horizontal flow biofilm reactor for wastewater treatment. Water Res., 44: 3819-3828.

Crab, R.; Avnimelech, Y.; Defoirdt, T.; Bossier, P. and Verstraete, W. (2007). Nitrogen removal techniques in aquaculture for sustainable production. Aquaculture 270, 1-14.

Delatolla, R.; Berk, D. and Tufenkji, N. (2008). Rapid and reliable quantification of biofilm weight and nitrogen content of biofilm attached to polystyrene beads. Water Res., 42: 3082-3088.

Devinny, J. S.; Deshusses, M. A. and Webster, T.S. (1998). Biofiltration For Air Pollution Control. Lewis Publishers. CRC Press, 2000 Corporate Blvd., N. W., Boca Raton, Florida, USA.

Eding, E.H.; Kamstra, A.; Verreth, J.A.J.; Huisman, E.A. and Klapwijk, A. (2006). Design and operation of nitrifying trickling filters in recirculating aquaculture: a review. Aquacultural Engineering 34, 234-260.

Freeman, K.S.(2012). Remediating Soil Lead with Fishbones. Environmental Health Perspectives. 120(1): a20-a21.

Gullicks, H. ; H. Hasan; D. Das; C. Moretti and Y. Hung. (2011). Review, Biofilm Fixed Film Systems. Water Journal. 
Jennings, P.A.; Snoeyink, V.L. and Chian, E.S.K. (1976). Theoretical model for a submerged biological filter. Biotechnology and Bioengineering, 18:1236-1240.

Mangunwardoyo, W. ; Sudjarwo, T. and Patria1, M. P. (2013). Bioremediation of effluent wastewater treatment plant bojongsoang bandung indonesia using consorsium aquatic plants and animals. IJRRAS 14 (1) : 150 -160.

Okuno, K., and Hirai, M. (2000). Microbial removal of nitrogen monoxide (NO) under aerobic conditions. Biotechnology Letters.22(1): 77-79.

Park, H.D.; Lee, S.Y. and Hwang, S. (2009). Redundancy analysis demonstration of the relevance of the temperature to ammonia oxidizing bacterial community composition in a full scale nitrifying bioreactor treating saline waste water. J. Microbiol. Biotechnol.,19: 346-350.

Seedorf, J., and Hartung, J. (1999). Reduction efficiencies of a biofilter and a bioscrubber for bioaerosols from two different piggeries. Berliner Und Munchener Tierarztliche Wochenschrift. 112(12): 444-447.

Selvi B. A, and Artuz, R. J. (2000). Biofiltration of air.

http://www.rensselaer.edu/dept/chem-eng/Biotech-Environ/MISC/biofiltration.html.

Skladany, G. J.; Deshusses, M. A.; Devinny, J. S.; Togna, A. P. and Webster, T. S. (1998). Biological systems: Biofilters. In: Odor and VOC Control Handbook. McGraw Hill Handbooks. McGraw Hill, 11 West $19^{\text {th }}$ Street, New York, USA.

Swanson, W. J. and Loehr, R. C. (1997). Biofiltration: fundamentals, design and operations principles and applications. Journal Of Environmental Engineering. 123 (6): 538-546, Jun. 1997.

Tal, Y.; Watts, J.E.M.; Schreier, S.B.; Sowers, K.R., and Schreier, H.J. (2003). Characterization of the microbial community and nitrogen transformation process associated with moving bed 
bioreactors in a closed recirculated mariculture system. Aquaculture 215, 187-202.

ter Haseborg, E.; Zamora, T.M.; Fröhlich, J. and Frimmel, F.H. (2010). Nitrifying microorganisms in fixed-bed biofilm reactors fed with different nitrite and ammonia concentrations. Bioresour. Technol., 101: 1701-1706.

van den Akker, B.; Holmes, M.; Cromar, N. and Fallowfield, H. (2008). Application of high rate nitrifying trickling filters for potable water treatment. Water Res., 42: 4514-4524.

van den Akker, B.; Holmes, M.; Cromar, N. and Fallowfield, H. (2010a).The impact of organic carbon on the performance of a high rate nitrifying trickling filter designed to pre-treat potable water. Water Sci. Technol., 61: 1875-1883. Water 2011, 3

van den Akker, B.; Holmes, M.; Short, M.D.; Cromarm, N.J. and Fallowfield, H.J. (2010b). Application of high rate nitrifying trickling filters to remove low concentrations of ammonia from reclaimed municipal wastewater. Water Sci. Technol., 65: 24252432.

Van Rijn, J. (1996). The potential of integrated biological treatment systems in recirculating fish culture-a review. Aquaculture 139, 181-201.

Van Rijn, J.; Tal, Y. and Schreier, H.J. (2006). Denitrification in recirculating systems: theory and applications. Aquacultural Engineering 34, 364-376.

Wichern, M.; Lubken, M. and Horn, H. (2008). Optimizing sequencing batch reactor (SBR) reactor operation for treatment of dairy wastewater with aerobic granular sludge. Water Sci. Technol., 58: 1199-1206.

Xue, H. J.K. (2007). Chemical fixation of metals in soil using bone char and assessment of the soil genotoxicity; 28(2):232-237.

You, J.; Das, A.; Dolan, E.M. and Hu, Z. (2009). Ammonia oxidizing archaea involved in nitrogen removal. Water Res., 43, 1801-1809. 
المعالجة البيولوجية لمياه الصرف للأسماك باستخدام مرشح حيوي

\section{خرزى معدل ومهوى}

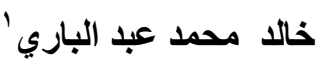

المعالجة البيولوجية هى طريقة تستخدم بشكل طبيعي الكائنات الحية (النباتات والحيو انات) في تحليل الملوثات وذلك عن طريق تكسير ها للمواد الخطرة وتحويلها إلى مواد أقل سمية أو غير سامة. هدف العمل البحثي على الحصول على مياه معالجة بطريقة مناسبة لإعادة استخدامها في ري المزارع، خصوصا مزارع الخضار او تستخدم في زر اعة الأسطح بحيث تعمل على تخفيف

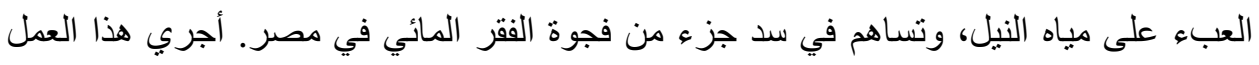
التجريبي في حوض زجاجى مقاوم لارتفاع ضغط ماء ومزود بنوعين من المرشحات الحيوية مرشح (A) ذو عنصر نرشيح إسفنى ، ومرشح خرزى (C) كريستال ذو حبييات بلاستيكية

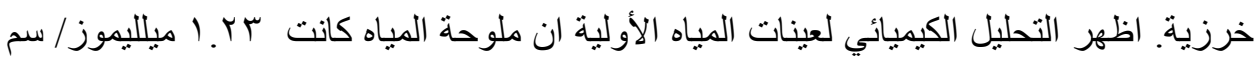
وذات درجة حموضة ع. V بعد I اليوما من بداية التجربة ازداد تركيز الأمونيا لعينات المياه

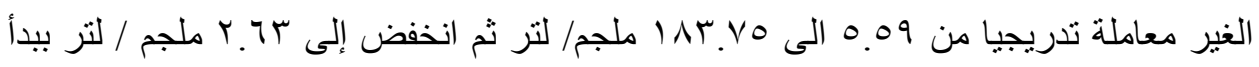

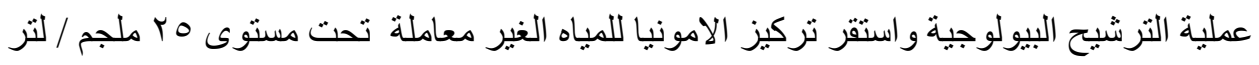

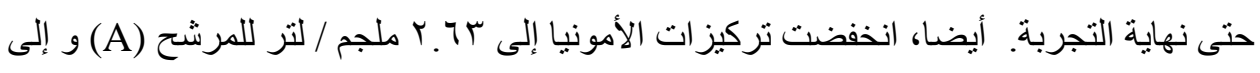
اب. اللمرشح (C) وكان ذلك راجعا الى عملية الغسيل العكسية للمرشحات و التى ادت الى الى

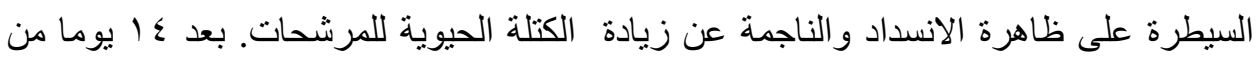

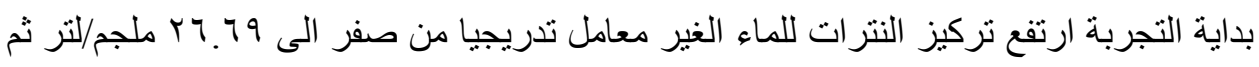

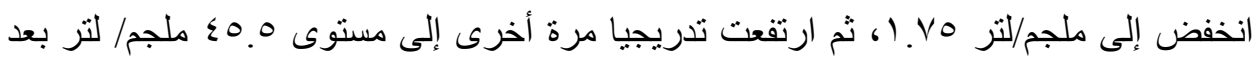

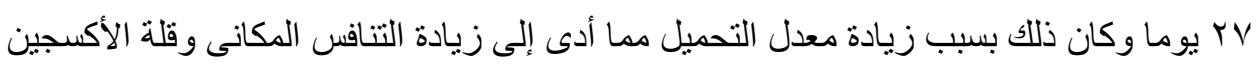

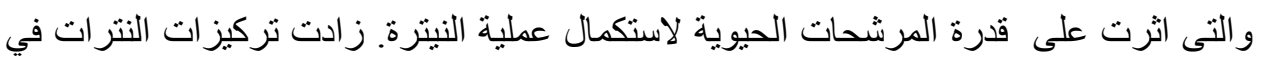

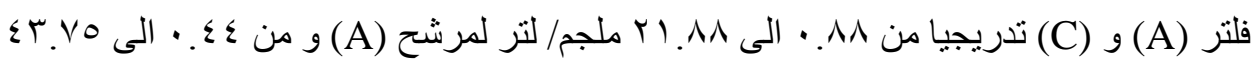
ملجم/لتر للمرشح (C) على التوالي، وذلك بعد / 1 يوما من بداية التجربة و التى اعتبرت كفتر ات

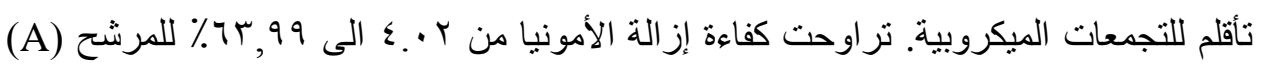

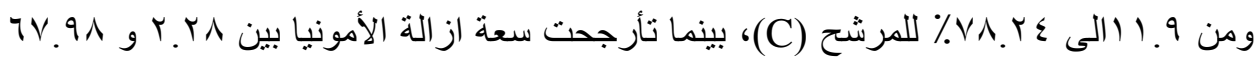

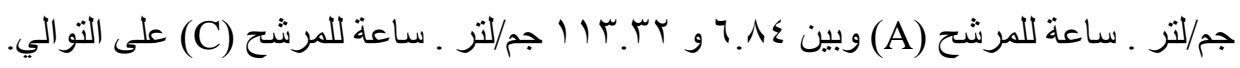

مدرس ـ قسم الهندسة الزراعية ـ كلية الزراعةـ جامعة القاهرة. 
اظهر المرشح الحيوى الخرزى المهوى (C) تفوقا في تركيز النترات، وارتفاع كفاءة إزالة

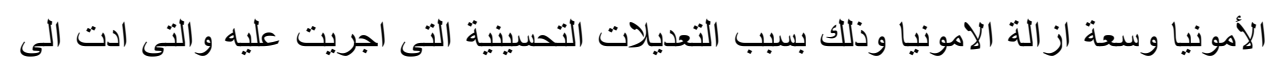

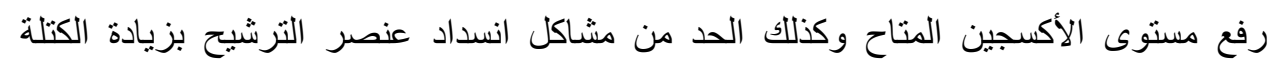

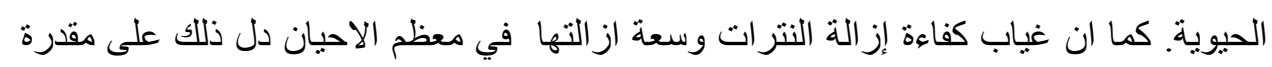

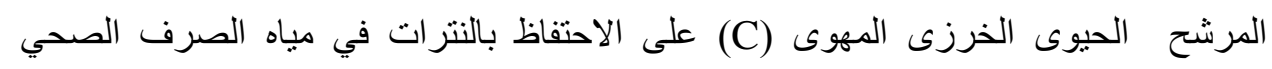
الأسماك الامر الذى يرفع من القيمة التسميدية لهذه المياه عند اعادة استخدامها.

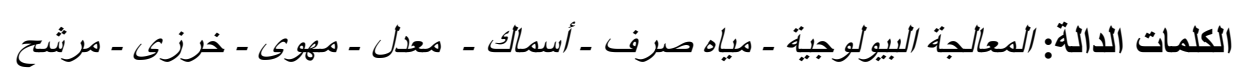
بيولوجي 